\title{
The Indian Ocean Tsunami in Swedish Newspapers: Nationalism after Catastrophe
}

\author{
Anna Olofsson \\ Risk and Crisis Research Center, Department of Social Sciences, Mid Sweden University, 831 \\ 25 Östersund, Sweden
}

This article was published in Disaster Prevention and Management 2011 see;

http://www.emeraldinsight.com/journals.htm?articleid=17003215

\begin{abstract}
Purpose - The purpose of this paper is to analyze how Swedish mass media constructed Sweden and Swedes during the first days after the Indian Ocean tsunami of December 26, 2004.
\end{abstract}

Design/methodology/approach - A qualitative content analysis of newspaper articles from four of the largest newspapers in Sweden was conducted.

Findings - The results show that the tsunami was framed as a Swedish disaster almost exclusively focusing on Sweden, Swedish victims and Thailand, and that there was a division between 'us' and 'them'. Two categories of 'us' and 'them' were identified in the coverage; On the international level Sweden, i.e. 'us', was glorified and contrasted with 'inferior' countries such as Thailand, 'them'; On the national level, the distinction between 'us' and 'them' was not as obvious, but by including particular experiences and practices and excluding others, lines are drawn between 'us' - ethnic Swedes - and 'them' - everyone else. The conclusion of the paper is that mediated frames of catastrophes are influenced by stereotypes and nationalistic values.

Research limitations/implications - The study is based on a qualitative analysis not possible to generalize to other cases. Additional quantitative studies would therefore be of value.

Practical implications - This study can be used in the education of crisis and disaster managers to make them aware of how underlying norms guide news coverage and encourage them to always critically consider information based on mass media reports.

Originality/value - This paper gives new theoretical and empirical insights into the way in which disasters contribute to recreating and maintaining the historical division between regions and people, both on a national and an international level.

Key words: catastrophe, mass media, postcolonial theory, 'us' versus 'them'

Paper type Research paper 
How to cite: Anna Olofsson, (2011) "The Indian Ocean tsunami in Swedish newspapers:

nationalism after catastrophe", Disaster Prevention and Management, Vol. 20 Iss: 5, pp.557 569

\section{Introduction}

Mass media play a central role during the initial period after a large disaster and crisis managers on different levels are often dependent on media both to receive and to give information. Media coverage also raises awareness among people in non-impacted regions and countries and stimulates relief aid and donations (Quarantelli, 1996; Quarantelli, 2005). This was not least true after the Indian Ocean tsunami in 2004 when large amounts of money were donated (Clark, 2005; Letukas and Barnshaw, 2008; Letukas, et al., 2009). Mass media framed victims in the impacted region according to societal stereotypes, something that Childs showed in her study of images of women as victims after the tsunami (Childs, 2006). The question this paper tries to answer is whether news media used comparative stereotyped frames of race and ethnicity in the coverage of the tsunami.

Important lessons can be learned from a better understanding of how mass media picture large disasters. Disasters and catastrophes create a window in the normal news flow where underlying norms, discourses and views of the world can be revealed. Even though journalists and editors try to stick to their practices, the time and information is scarce at a catastrophe, which make the news less touched up and politically correct. This paper focuses on the consequences of this change for how a nation and its inhabitants are framed by mass media directly after a major disaster. Hence, the aim is to analyze how Swedish mass media constructed Sweden and Swedes during the first days after the Indian Ocean tsunami of December 26, 2004. Insights to how biases, prejudice and even xenophobia and nationalism influence news coverage at disasters will help responsible actors to make better decisions. Because awareness of the fact that the concept 'disaster' is loaded with assumptions of who is vulnerable and who is capable can help for example crisis managers to act in a less biased way and to avoid reproduction of traditional conduct.

Sweden is an interesting case since it is a country spared from natural disasters like earthquakes, droughts, tornados and tsunamis. It is also a country spared from overt racism and by many is used as a role model for equality (cf. Towns, 2002). Up until the 1960's Sweden hardly experienced immigration, but since then the number of foreign-born people in Sweden has quadrupled and constituted 13 percent of the population in 2006 (Marklund, 2007). One fourth were born in one of the other Scandinavian countries, predominantly Finland, and one fourth in Asia where Iraq is the main country of emigration. Sweden has also witnessed a relatively small but increasing trend of immigration from South East Asia, and in 2006 Thailand was the seventh largest emigration country (Marklund, 2007). 


\section{Theory and previous research}

No event in modern history has received such great media attention in Sweden as the Indian Ocean tsunami (Andersson Odén, et al., 2005). Much of the coverage was critical particularly of the slow official handling of the catastrophe in Sweden (Grandien, et al., 2005; Letukas, et $a l ., 2009$ ). This is also the focus of a good deal of the research following the tsunami (for an overview see Kivikuru and Nord, 2009), while other aspects such as underlying structures of inequality and stereotypes, have not been investigated to the same extent. ${ }^{\mathrm{i}}$

I do not agree with Garner (1996, p. 14) who argues that journalists have a pedagogical role telling people how to respond at possible catastrophes. This is a responsibility of crisis managers and authorities. However, for most people the mass media constitute the prime source of information at catastrophes like the tsunami (Galtung and Ruge, 1965; Jarlbro, 2004; Rattien, 1990). The journalistic practices of selecting news have an influence on which catastrophes are covered and which are not. This explains why for example hurricane Katrina, which struck the United States in 2005, received far more attention in Swedish media than hurricane Stan, which struck Guatemala the same year, although the latter killed more than twice as many people as the former (Sällström, 2006). ${ }^{\text {ii }}$ What is covered by mass media will constitute what people have opinions about and at the same time, journalists and editors adapt the selection of news to fit what they believe will be of interest for the public.

In this study postcolonial theory and particularly the analytic pair 'us' and 'them' is applied on news coverage of the Indian Ocean tsunami. Postcolonial theory is a critical endeavor to analyze modernity and the significance of (Western) imperialism both for the colonized and the colonizer (Bhabha, 1994; Hall, 1997; Said, 1979). Colonialism represents not only the actual act of one nation colonizing another, but also the hegemonic discourse ${ }^{\mathrm{iii}}$ of Western modernity, through which the whole world is understood and has been understood for centuries (Childs and Williams, 1997). The construction of who 'we' are is bound to the construction of others; however, due to stratification based on the universalizing discourse of Western modernity, some will be considered superior to 'others' (cf. Bhabha, 1994; Said, 1979; Shome and Hegde, 2002). According to Hall (1997), this is a process of representations transferring into stereotypes which fixate particular characteristics of 'them', characteristics that over time become naturalized, i.e. perceived as the individual's, group's or population's inner traits and true character (Molina, 2005; Schmauch, 2006). Studies of mass media can reveal the reproduction of knowledge about 'others' and 'other' cultures in relation to the 
How to cite: Anna Olofsson, (2011) "The Indian Ocean tsunami in Swedish newspapers:

nationalism after catastrophe", Disaster Prevention and Management, Vol. 20 Iss: 5, pp.557 -

569

global hegemonic order as well as representations of different national groups in the coverage of globalization. Communication scholars largely agree that the ability of the mass media to categorize and make definitions constitutes power (Asp, 2002), since its representation of events and people transforms into 'common' knowledge (cf. Hall, 1997).

Although research indicates that journalistic practices are much the same in disasters as in regular reporting (Bennett and Daniel, 2002; Nord and Strömbäck, 2005), the initial phase of a disaster is particular. It is characterized by getting journalists to the impacted area, organizing extra editions and programs etc. (Andersson Odén, et al., 2005). Further, the coverage becomes more extensive and dramatic, more improvization is allowed, and sources are not checked as thoroughly as they are under normal circumstances. Hence, the news becomes more stereotyped and biased and maybe most interesting, tendentious and ideologically framed. Minority groups, particularly people with a migrant background, are often ascribed negative or 'exotic' characteristics, and as being passive victims rather than active agents, that reflect societal stereotypes (Vergeer, et al., 2000; Voorhees, et al., 2007), not seldom in terms of 'us' and 'them' (Brune, 1998; Sonwalkar, 2004). However, previous studies show that genres differ in this respect; culture, popular and consumer journalism tend to use these frames to a lesser extent than traditional, and higher status, genres such as national, international and economic journalism (Sonwalkar, 2004; Vergeer, et al., 2000). In a similar way, war journalism has a propensity to not only glorify the nation but also, in the case of Sweden, the West (Nohrstedt, 2006).

These are examples of how the 'second face' of discrimination works in a globalized world; how 'we' create an image of 'us' by exclusion and stigmatization of 'them' (cf. Mattsson, 2005). The national media also serve to generate a 'us' community, where experiences, practices, norms and values of 'other' groups are regularly ignored or used as a contrast to 'our' experiences, practices and values (Brune, 2000; Camauër, 2005; Eriksson, 2006; Nohrstedt, 2006). As a consequence, people with a migrant background and other minority groups cannot identify with the reality constructed by the mass media, and hence are excluded from the information flow or seek alternative communication channels (Christiansen, 2004; Lindell and Perry, 2004). To avoid a situation where large parts of the population do not get attention and/or relevant information professionals in the field of disaster prevention and management need more knowledge about how mass media construct pictures of the population at catastrophes. 


\section{Method}

A qualitative content analysis was performed to explore how Swedish news media covered people and nations directly after the Indian Ocean tsunami. Four of the most widely circulated national newspapers in Sweden were selected for analysis. Aftonbladet (tabloid) is Sweden's largest newspaper with a daily circulation of about 380,000 (Tidningsutgivarna, 2009). Dagens Nyheter is Sweden's second largest daily newspaper and the largest morning newspaper with an average daily circulation of 340,000, and it is considered by many as the opinion-leading newspaper in Sweden (Strömbäck, 2000). Expressen (taboid) is the third largest newspaper with an average circulation of 305, 000. Last, Svenska Dagbladet is Sweden's fifth largest daily newspaper, and third largest morning newspaper with a daily circulation of 195,000 (Tidningsutgivarna, 2009). The time period of study includes the eight days following initial impact, from December 26, 2004 to January 3, 2005. This period was chosen because it allowed for detailed analyses of the immediate post-impact period.

All articles published in the selected newspapers were identified in the databases Presstext and Mediearkivet, using three search phrases: 'tsunami*', catastrophe*' and 'flood wave*', resulting in almost four hundred articles. A limitation with the chosen material is that images and layout could not be included in the analysis due to the on-line format of the data bases. Discourse analysis is common in postcolonial analyses but since the material was so extensive a qualitative content analysis was applied (Bauer and Gaskell, 2000). First a simple perusal with the help of the software program ATLAS.ti 5.2 was made to categorize data into a few preconceived but open codes including actor, event, victim, origin, and location. Any mentioning of people, particularly those with a migrant background living in Sweden, was also coded. Notes and memos were used in the process of coding to capture emergent themes, not least issues related to descriptions of 'us' and 'them'. Secondly, a reading of notes and memos were made to identify significant articles and to create specific codes to illustrate how the newspapers construct involved actors at different levels, like victims, Swedes, Thai people, Indonesians as well as nations like Sweden, Thailand, Indonesia, the US etc. Based on the second analysis a third reading was made with a smaller number of articles. These were analyzed to identify frames guided by the theoretical point of departure. Identifying media frames can be described as a way of revealing underlying discourses (Ploughman, 1995; Scheufele, 1999; Tuchman, 1978), and frames are here seen as abstract notions that serve to organize or structure social meanings; at once a product of journalistic practices and a 
How to cite: Anna Olofsson, (2011) "The Indian Ocean tsunami in Swedish newspapers: nationalism after catastrophe", Disaster Prevention and Management, Vol. 20 Iss: 5, pp.557 569

reproduction of societal norms and values. The identified frames are presented in the following section.

\section{Findings}

The findings describe three dominant frames: 'Bringing what is distant close', 'Us', the native Swedes', and 'Putting 'us' in perspective: Sweden is a great country', which are analyzed in accordance with the concepts of 'us' and 'them'. The categorization of 'us' and 'them' is found on both a national and an international level, corresponding to a nativist and a nationalistic discourse. The first two frames apply a national level of 'us' and 'them', whereas the third applies an international level.

\section{Bringing what is distant close}

The investigated newspapers covered the tsunami as if Sweden actually was one of the impacted countries in the Indian Ocean. Stories about relief aid and crisis management focus not only on Swedish relief workers but also concern Swedish hospitals' preparedness for receiving the homecoming victims. The fact that national media tend to focus on the country's own citizens is well-known. However, by providing a dominant frame focusing on Swedish tourists trapped in Thailand, the Swedish media substantially narrowed the scope of the catastrophe from thirteen nations to mainly one and turned an international catastrophe into a domestic disaster.

Further, the focus in the articles mixes 'tourists' with the Swedish victims. 'Tourists' are often mentioned, but typically it is Swedish tourists, and as a consequence of Swedish tourists mainly being located in Thailand, and some in Sri Lanka, it is these places that get coverage. Thailand is described as a (Swedish) tourist destination and when places like Patong Beach, Pong Suk and Phi Phi Island were destroyed it was the devastation of a 'Swedish paradise'. Two examples of headlines: 'A paradise smashed to pieces' (DN Jan 3, 2005: A07) and 'The tourists' paradise island wiped out' (SvD Jan 3, 2005: 8) show how Thailand is identified as an idealized tourist destination. In this way, the geographically distant Thailand is symbolically brought closer to Sweden. The use of 'Swedish-' [svensk-] as a prefix, in descriptions of places and in metaphors, further overrides the geographical distance: in other words, by highlighting national interests the catastrophe is figuratively brought closer to Swedish readers. Dagens Nyheter writes for example (Dec 28, 2004): A11): 'The hotel was in the Swedish-paradise of Pong Suk, at the beach of the wonderful bay that 
How to cite: Anna Olofsson, (2011) "The Indian Ocean tsunami in Swedish newspapers: nationalism after catastrophe", Disaster Prevention and Management, Vol. 20 Iss: 5, pp.557 569

now once again lay calm and glittery.' and Svenska Dagbladet publishes an article describing the tsunami scenario (Jan 2, 2005: 12): '05.42: Tourists missing in Thailand. Already at this time there is information about fatalities in the area of the Swedish-hotels.'

Considering the incomprehensible suffering and death toll in countries such as Indonesia it is remarkable, regardless of selection criteria based on geographical and cultural closeness, that the discourse in Swedish newspapers is about Sweden and Swedish victims. This one-sidedness of the coverage is discussed to some extent by the newspapers themselves. However, rather than putting things in perspective, the domestication is defended as 'natural'. This example is from Dagens Nyheter's editorial page (Dec 30, 2004: A02):

Focusing so much on the Swedish victims is sound and natural. It is in our country, in our fellowship, that we have to deal with the incomprehensible tragedy that neighbours, friends, relatives and colleagues have experienced. It is the strength of the national state to feel solidarity and empathy outside of the immediate circle, to participate in the larger community that consists of our fellow citizens.

This statement from the editor of Dagens Nyheter justifies the domestic, and nationalistic, standpoint in times of a catastrophe and that it is a deliberate choice of Swedish journalists to frame the tsunami as a Swedish catastrophe.

\section{'Us, ' the native Swedes}

By continuing with the above citation drawn from Dagens Nyheter's editorial page and highlight some of the statements: Focusing so much on the Swedish victims is sound and natural. It is in our country, in our fellowship, (...) to participate in the larger community that is made up of our fellow citizens. [emphases in bold are added by the author], the following question can be asked; Who is included in 'our country' and 'the larger community'? and who is covered by 'our fellowship' and 'our fellow citizens'? These are questions related to the construct of 'us', and who is included in 'us'. One answer already given is that 'us' comprises Swedish tourists, but the coverage is of course not entirely devoted to tourists. The phrases in the citation above are common in the coverage, and to answer the questions the articles have to be further explored.

As shown in the following citations, the use of examples and names, taken for granted expressions and who is interviewed, can reveal the underlying meanings of 'us'. For example, Expressen published the following text (Jan 1, 2005):

This is a catastrophe that strikes Sweden personally. The usual abstract and incomprehensible death toll in natural disasters has gotten names and faces: Sofia, Kent, 
Clara, Sven-Anders, Helena, Max, Markus, Per-Åke and many hundred more, maybe more than a thousand. (...)

This citation illustrates once again that the catastrophe is Swedish, but more importantly it identifies who the victims are thought to be through the use of their names. The names are all traditional ethnic Swedish names, and even if Kent, Clara and Max can be considered as more modern names they are not examples of common names of people from the impacted region.

Furthermore, in the coverage it is more or less taken for granted that people in Sweden lack prior experience of disasters. It is a fact that the territorial region of Sweden is rarely impacted by natural hazards or catastrophes, and relatively few other catastrophes have happened. However, many people living in Sweden have experienced war, natural disasters and other catastrophes in other parts of the world. This is not discussed or even mentioned: on the contrary, the historically secure situation in Sweden is taken for granted, while experience of other contexts is expected to be obtained as tourists during temporary visits. The scientific reporter Karin Boys writes in Dagens Nyheter (Jan 2, 2005: A33):

For the first time we Swedes have been forced to understand what a tsunami is. The phenomenon does not exist in our own calm waters. But it is well known in other parts of the world.

In a sublime way this citation shows what goes without saying: Swedes do not have any experience of disasters. The definition of 'Swedes' only includes ethnic Swedes, whose only experience of natural disasters comes from tourism. At the same time, the citation shows that the journalist is well aware that tsunamis are neither unusual nor a new phenomenon in 'other parts of the world'. However, a relatively large number of people in Sweden have their origins in areas where such natural disasters are common.

Yet another way of revealing who 'we' are, and who counts as part of 'our community' in the coverage, is to look at human interest articles and choice of interviewees. However, human interest articles with people from the impacted area living in Sweden are very rare in the material. Even on-the-spot reports and interviews in Thailand are often made with Swedes who are living in Thailand, rather than native Thai people, as in this citation from Svenska Dagbladet (Dec 30, 2004: 8): The situation is still very chaotic, says Thorleif Håwi, a Swede living in Phuket, who, like many other Thai-Swedes, has made voluntary contributions.

The only coverage that reflects upon the one-sidedness is letters-to-the-editor by the readers and articles on the cultural pages. News and editorials, which dominates the coverage, keep the focus on 'us'. Both the defense and the criticism of the one-sidedness indicate that 
How to cite: Anna Olofsson, (2011) "The Indian Ocean tsunami in Swedish newspapers: nationalism after catastrophe", Disaster Prevention and Management, Vol. 20 Iss: 5, pp.557 569

this is more than just a matter of journalistic practices and editorial selection processes. The focus on ethnic Swedes rather than other people in the impacted regions, as well as the lack of attention given to people with a migrant background is by some perceived as problematic, but not by those who are responsible at the newspapers.

\section{Putting 'us' in perspective: Sweden is a great country}

This frame covers how the newspapers compare Sweden with other countries on an international level, and emphasizes its comparative advantages; i.e., Sweden is a great country. This frame is manifested particularly in the coverage of international relief aid. Right from the first day after the catastrophe, December 27, Dagens Nyheter writes about relief aid, pointing out Sweden's prompt response to the International Red Cross appeal for money (Dec 27 2004: A09):

Sweden helps with the relief aid after the natural catastrophe. Two communication experts are going to Sri Lanka where an airplane with necessities is also being sent. In addition, Sweden donates five million kronor to the Red Cross relief action.

The UN, EU and other countries are also mentioned, but it is the Swedish efforts that is in the centre of attention, because, even if the whole world comes together to help the victims in the Indian Ocean, Sweden is pictured as the greatest helper. Indeed, the US and Japan are reported as giving more money, but little Sweden donates the fourth most of all countries, according to several articles. In relation to Norway the tone becomes even more nationalistic; e.g., Dagens Nyheter points out that Norway is donating less than Sweden despite its large incomes from oil production (Jan 2, 2005: A16):

On Saturday evening the total sum had passed the equivalent of 13 billion Swedish kronor, with Japan as the greatest donor giving more than 3.3 billion kronor. (...) Finland has for example only promised 41 million kronor and rich oil-producing Norway, which lost many citizens, only donates 110 million kronor.

The relief aid is almost described as a football tournament: the question is not about the receivers and their particular needs, but rather about who is giving the most. Being a relatively small country, Sweden is compared by the journalists with its rivals, and praised for doing so well. However, this is not only a matter of glorifying national efforts, but also a way of identifying Sweden as having the capacity to give, while Thailand, Sri Lanka and other impacted countries are identified as in need of receiving. There is an underlying image of the superiority of the giving over the taking. Dagens Nyheter writes (Jan 2, 2005: A04): 
Now it is a matter of helping those who are affected. When nature is angry we are all in the same nutshell: rich and poor, black and white. The tsunami made no difference between the beggar and the tourist.

The intention of this statement seems to be to overcome boundaries between 'us' and 'them' and to encourage solidarity between people and nations. However, at the same time it defines the difference between 'us' in Sweden, the tourists and helpers, and 'them' in the impacted region (more precisely Thailand) as beggars and in need of help. Thus, Swedes will come to rescue and help, since the impacted area and the inhabitants are less able to handle a disaster than Sweden and Swedes. There is an implicit assumption that countries such as Thailand cannot handle a catastrophe like this, and the frame through which the situation is understood is so impregnated with a white Western perspective that no one seems to reflect on the fact that catastrophes of the size of the tsunami frequently occur around the globe, not least in South East Asia. The one country without experience is Sweden. Thus, even without earlier experience, 'Sweden is pictured as greater and better prepared than the countries of the impacted regions. Hence, the categorization of 'us' and 'them' on an international level is quite explicit in the coverage, expressed through a domestic or even nationalistic frame with a clear hierarchy between the two categories.

There are also examples where Thailand and the other impacted countries are pictured as being economically and even morally inferior. One example is this eyewitness report from a Thai hospital (DN Jan 2, 2005: A17):

They called it the 'slaughter house'. - Cockroaches were running around and it was dirty; in the restrooms there was excrement everywhere. (...) - This was a sudden catastrophe and they have no resources. (...) Now it will be great to come home and get real [health] care...

Not only is the standard between Thai and Swedish hospitals compared, but indirectly through the interview with a Swedish victim, Thai healthcare is questioned. The difference in moral standards between Sweden and the impacted region is clearly stated in an editorial piece in Svenska Dagbladet (Dec 31, 2004: 4):

In Sweden the wave has released humanity, but there are reports saying that in Aceh, where the need is great, it is the law of the jungle that prevails. It is the strongest that make their way when the food is distributed.

Instead of taking the situation for what it is, chaotic and desperate, journalists compare and contrast the difference in reaction between one region of the world and another. Interestingly, on the cultural pages there are a few articles focusing on the relation between the tourists, 
How to cite: Anna Olofsson, (2011) "The Indian Ocean tsunami in Swedish newspapers:

nationalism after catastrophe", Disaster Prevention and Management, Vol. 20 Iss: 5, pp.557 -

569

'us', and the local inhabitants, 'them'. One journalist writes on the cultural pages of Dagens Nyheter (Jan 4, 2005: B04):

(...) Slim Thai people are moving as fast as weasels between the tables. Between the tourists and the locals there is this film. Or is it a glass wall? Something that effectively separates the different human groups, and makes them ignore each other: the selfsufficient Swedes in their semi-fictitious holiday paradise and the Thai people in their rough and ready everyday life.

This article deals with what other articles cover in a more indirect way: i.e., something happens to the power relation between the tourists and the local population when the tsunami strikes. Earlier, people have clear roles with a relative position: the visiting (and paying) tourists play the leading part, while the local population serve them (and get paid). After the tsunami, the tourists become helpless victims, dependent on the generosity of native people, where money no longer is a mean to an end. Maybe it is this broken, and reversed, power relation that makes the anger directed towards Swedish authorities and their lack of relief aid during the initial phase so great. One way to re-establishing the positions is to boost the generosity of Swedes and Sweden through the stories of donor relief.

\section{Conclusions}

This paper shows how Swedish national newspapers tended to construct nationalistic discourses in their coverage of the impact phase of the South East Asian tsunami. The analysis of 'us' and 'them' identifies two levels in the coverage: the international level where nationalism can be said to influence the construction of the disaster, and the national level where nativist tendencies are recognized. Overall, there is a tendency to picture 'our community' and 'us' as corresponding to traditional stereotypes of the country and its inhabitants in an uncritical way. For example, Swedes are pictured as not having experience of natural disasters, but are at the same time seen as comparatively better at handling catastrophes than people from other countries including the impacted region. This shows how underlying nationalism overrides the national and international level in the coverage, by excluding and disqualifying 'others' on both levels.

The division between 'us' and 'them' on the national level is initially hard to detect since it is a matter of the second face of discrimination. All those who do not, or cannot, identify themselves with the representation of Swedes as tourists, as being without prior experience of disasters etc., are excluded from 'us', thus 'them' are effectively excluded from the coverage. Hence, it is not a question of a negative frame where 'them' is ascribed traits 
How to cite: Anna Olofsson, (2011) "The Indian Ocean tsunami in Swedish newspapers: nationalism after catastrophe", Disaster Prevention and Management, Vol. 20 Iss: 5, pp.557 569

and traditions not wanted by the majority community: on the contrary, 'them' are kept out of the coverage altogether. It was 'us' who for the first time had suffered a natural disaster of this kind of dignity; 'them' were just extras in the story of 'our' misery. Not only are 'others' excluded, but 'us' are defined according to the overall norms of the West and being part of the majority population (cf. Frankenberg, 1993). Consequently, after the tsunami the mass media framed 'us' as people travelling abroad on vacation, with financial resources to donate money, and not least as an ethnically homogeneous population. Those who do not identify with this image are excluded from 'us'.

The nationalist approach found in the coverage of international relations between Sweden and other countries constructs an 'us', as Hall (1997) states, clearly bound to the construction of 'others', where the latter are framed according to simplistic stereotypes such as tight-fisted, unrefined and incompetent, creating an 'us' as their antithesis. Hence, this indicates a rather widespread and naturalized view of 'them' as inferior to 'us' (cf. Molina, 2005). However, there is no strict dichotomy in the coverage. Although Sweden is viewed as the greatest country, with the exception of the government, there is also a division between 'the West' and 'the rest'. The mass media in other countries, both in Scandinavia and other parts of the West, create similar frames where their own country as well as the West at large, is superior to other countries in general and the impacted region in particular (e.g. Kivikuru, 2006; Kivikuru and Nord, 2009; Letukas, 2008; Letukas, et al., 2009). This indicates that in the aftermath of catastrophes it is not only solidarity in terms of donor relief that arises, but also nationalism and historically rooted power hierarchies between countries and regions of the world.

However, there is a moment when the (glass) wall between the local people and the tourists is torn down: the mass media write about how fund raising has never before been so successful, how Swedes volunteer to help local people just as the latter have helped them etc. There is a moment of destabilization of identities and relations at and directly after a catastrophe that narrows the distance between tourists and native people (cf. Shome and Hegde, 2002). But there is also the uncovered 'White and Western' Sweden, which appears in the country's leading newspapers. Journalistic practices and selection processes interact with societal norms and established power relations. In chaotic and stressful situations this kind underlying discourses get revealed and news as well as donations and relief aid, work as a way to re-stabilize patterns of identity. The images given by media create powerful frames for professionals in disaster management as well as people in general. Mass media are powerful 
through their ability to create images and representations of what is normal and desired and what is not. By using the concepts of 'us' and 'them', this analysis reveals the taken for granted social and cultural 'white' context in the wealthy part of the world. 'We' can turn outward and show compassion by donating money to re-establish 'our' shattered paradise, since it is so precious to 'us', and at the same time 'we' re-establish both place and identity of 'others' - 'we' do not want to reverse the relation of power. Studies of the recovery process after the tsunami also show that much of the focus is on tourism and not on local communities and their recovery (Lebel, et al., 2006).This also explains why almost all the money donated in Sweden was given to Thailand, rather than Indonesia which faced the largest impact of the tsunami.

This paper gives new insights into the way in which disasters contribute to recreating and maintaining the historical division between regions and people, both on a national and an international level, insights important for professionals working with disaster preparedness and management. As a crisis manager it is important to recognize that not only mass media but the whole society is impregnated by taken for granted views of people and countries to avoid that these views guide decisions and actions at crises and disasters. 


\section{Newspaper articles:}

Dagens Nyheter. (2004), "Sverige skickar experter till Sri Lanka", 27 December, p. A09.

Dagens Nyheter. (2004), 'DN I PHUKET: 'Minst 30 döda låg på stranden vid mitt hotell'”, 28 December, p. A11.

Dagens Nyheter (2004), "UTLANDSRÖSTER" 30 December, p. A11.

Dagens Nyheter. (2005), "Den förtvivlade längtan efter ett lyckligt slut", 2 January, p.A02.

Dagens Nyheter. (2005), "1,1 miljard dollar till tsunamikatastrofens offer", 2 January, p. A16.

Dagens Nyheter. (2005), "Pojken som vann över vågorna. Efter två dagar återförenades

Hannes Bergström med sin skadade pappa", 2 January, p. A17.

Dagens Nyheter. (2005), "Naturens krafter kommer närmare", 2 January, p.A33.

Dagens Nyheter. (2005), "Ett paradis i spillror" 3 January, p. A07.

Dagens Nyheter (2005), "Läsarreaktioner efter katastrofen" 3 January, p.A31.

Dagens Nyheter (2005), "Glasväggen är borta. Paradiset ligger i spillror.", 4 January, p. B04

Expressen. (Jan 1, 2005)," Sorg och solidaritet", 1 January.

Svenska Dagbladet (2004), 30 December, p. 8.

Svenska Dagbladet. (2004), "Och klockan fortsätter att ticka”, 31 December, p. 4.

Svenska Dagbladet. (2005), "Många av svenskarna dödas nästan genast” 2 January, p. 12.

Svenska Dagbladet. (2005), "Turisternas paradisö förintades” 3 January, p. 8.

\section{References:}

Andersson Odén, T. Ghersetti, M. and Wallin, U. (2005), Tsunamins genomslag. En studie av svenska mediers bevakning, KBM:s temaserie. Krisberedskapsmyndigheten, Stockholm.

Asp, K. (2002), "Medialiseringen av det offentliga samtalet'. In Holmgren, A. (Ed), Fackets och politikens medialisering - Klasskampen på en åsiktsmarknad," LO idédebatts skriftserie, LO, Stockholm.

Bauer, M.W. and Gaskell, G. (2000), Qualitative researching with text, image and sound, SAGE, London.

Bennett, R. and Daniel, M. (2002), "Media reporting of third world eisasters: The journalist's perspective", Disaster prevention and management, Vol. 11 No.1, pp. 33-42.

Bhabha, H.K. (1994), The location of culture, Routledge, London.

Brune, Y. (1998), Mörk magi i vita medier. Svensk nyhetsjournalistik om invandrare, flyktingar och rasism, Carlssons Bokförlag, Stockholm.

Brune, Y. (2000), Stereotyper i görvandling. Svensk nyhetsjournalistik om invandrare och hlyktingar, Mena-projektet. Delstudie 11, Regeringskansliet, UD, Stockholm.

Camauër, L. (2005), En kartläggning: Minoritetsmedier och minoritetsmediepolitik i Sverige, Styrelsen för psykologiskt försvar, Stockholm.

Childs, M. (2006), "Not through women's eyes: Photo-essays and the construction of a gendered tsunami disaster", Disaster prevention and management, Vol. 15 No.1, pp. $202-12$.

Childs, P. and Williams, R.J.P. (1997), An introduction to post-colonial theory, Prentice Hall, London.

Christiansen, C.C. (2004), "News media consumption among immigrants in europe. The relevance of diaspora", Ethnicities, Vol. 4 No.2, pp. 185-207.

Clark, N. (2005), "Disaster and generosity", Geographical Journal, Vol. 171 No.4, pp. 38486. 
How to cite: Anna Olofsson, (2011) "The Indian Ocean tsunami in Swedish newspapers: nationalism after catastrophe", Disaster Prevention and Management, Vol. 20 Iss: 5, pp.557 569

Eriksson, G. (2006), "Det här är lycka'. Om sportjournalistikens inkluderande mekanismer," in Camauër, L and Nohrstedt, SA. (Eds.), Mediernas vi och dom. Mediernas betydelse för den strukturella diskrimineringen, Fritzes, Stockholm.

Galtung, J. and Ruge, M. (1965), "The structure of foreign news: The presentation of the Congo, Cuba and Cyprus crises in four foreign newspapers", Journal of International Peace Research, Vol. 2 No.1, pp. 64-90.

Garner, C.A. (1996), "Reconstructing Reality: Interpreting the Aeroplane Disaster News Story", Disaster prevention and management, Vol. 5 No.3, pp. 5-15.

Grandien, C. L. Nord and Strömbäck, J. (2005), Efter flodvågskatastrofen. Svenska folkets åsikter om och förtroende för myndigheter, medier och politiker 2005, Krisberedskapsmyndigheten, Stockholm.

Hall, S. (1997), Representation: Cultural representations and signifying practices, Sage, London.

Jarlbro, G. (2004), Krisjournalistik eller journalistik $i$ kris?, KBM:S temaserie, Krisberedskapsmyndigheten, Stockholm.

Kivikuru, U. (2006), "Tsunami communication in Finland: Revealing tensions in the senderreceiver relationship", European Journal of Communication, Vol. 21 No.4, pp. 499520.

Kivikuru, U. and Nord, L, (Eds.), (2009), After the tsunami: Crisis communication in Finland and Sweden, Nordicom, Göteborg

Lebel, L. Khrutmuang, S. and Manuta, J. (2006), "Tales from the margins: Small fishers in post-tsunami Thailand", Disaster prevention and management, Vol. 15 No.1, pp. 124-34.

Letukas, L. (2008), "Is aid a social problem? Cross-national media constructions of relief efforts following the Indian Ocean tsunami", University of Delaware. Newark.

Letukas, L. and Barnshaw, J. (2008), "A world-system approach to post-catastrophe international relief", Social Forces, Vol. 87 No.2, pp. 1063-87.

Letukas, L. Olofsson, A and Barnshaw, J. (2009), "Solidarity triumphs catastrophe? An empirical and theoretical analysis of post-tsunami media in Sweden and the United States", in Nord, L and Kivikuru, U. (Eds.), Afer the Tsunami. Crisis Communication in Finland and Sweden, Nordicom, Göteborg.

Lindell, M.L. and Perry, R.W. (2004), Communicating environmental risks in multiethnic communities, Sage, Thousad Oaks.

Marklund, H. (2007), "Finländarna fortfarande flest", Välfärd. Avaliable at: www.scb.se, (assesed 1 May 2010).

Mattsson, K. (2005), " Diskrimineringens andra ansikte - Normerande svenskhet och "Det vita västerländska", in De Los Reyes, P. and Kamali, M. (Eds.), Bortom vi och dom Teoretiska reflektioner om makt, integration och strukturell diskriminering. Fritzes, Stockholm.

Molina, I. (2005), "Rasifisering", in De Los Reyes, P. and Kamali, M. (Eds.), Bortom vi och dom-Teoretiska reflektioner om makt, integration och strukturell diskriminering. Fritzes, Stockholm.

Nohrstedt, SA. (2006), "Krigsjournalistiken och den struturella diskrimineringen," in Camauër , L and Nohrstedt, SA. (Eds.), Mediernas vi och dom. Mediernas betydelse för den strukturella diskrimineringen, Fritzes, Stockholm.

Nord, L. and Strömbäck, J. (2005), Hot på agendan. En analys av nyhetsförmedling om risker och kriser, Krisberedskapsmyndigheten, Stockholm.

Ploughman, P. (1995), "The American print news media construction of 5 natural disasters", Disasters, Vol. 19 No.4, pp. 308-26. 
Quarantelli, E.L. (1996), "Local mass Mmedia operations in disasters in the USA", Disaster prevention and management, Vol. 5 No.5, pp. 5-10.

Quarantelli, E.L. (2005), "Catastrophes are different from disasters: Some implications for crisis planning and managing drawn from Katrina", avaliable at: http://understandingkatrina.ssrc.org/Quarantelli/ (accessed 26 April 2010).

Rattien, S. (1990), "The Role of the Media in Hazard Mitigation and Disaster Management", Disasters, Vol. 14 No.1, pp. 36-45.

Rodriguez, H. Wachtendorf, T. Kendra, J and Trainor, J. (2006), "A snapshot of the 2004 Indian Ocean tsunami: Societal impacts and consequences", Disaster prevention and management, Vol. 15 No.1, pp. 163-77.

Said, E.W. (1979), Orientalism, Vintage Books, New York.

Scheufele, D.A. (1999), "Framing as a theory of media effects", Journal of Communication, Vol. 49 No.1, pp. 103-22.

Schmauch, U. (2006), Den osynliga vardagsrasismen, Umeå university, Umeå.

Shome, R. and Hegde, R.S. (2002), "Postcolonial approaches to communication: Charting the terrain, engagin the intersections", Communicaiton Theory, Vol. 12 No.3, pp. 249-70.

Sonwalkar, P. (2004), "Mediating otherness: India's English-language press and the northeast", Contemporary South Asia, Vol. 13 No.4, pp. 389-02.

Strömbäck, J. (2000), Makt och medier. Om samspelet mellan medborgare, medier och politiska makthavare, Studentlitteratur, Lund.

Sällström, J. (2006), "Ignorerade Kriser 2005", avaliable at: www.diakonia.se (accessed 1 August 2008).

Tidningsutgivarna. (2009), "Svensk dagspress 2009. Fakta om marknad och medier", avaliable at: from www.tu.se (accessed 28 April 2010).

Towns, A. (2002), "Paradoxes of (in)Equality: Something is rotten in the gender equal state of Sweden", Cooperation and Conflict, Vol. 37 No.2, pp. 157-79.

Tuchman, G. (1978), Making news. A study in the construction of reality, The Free Press, New York.

Vergeer, M. Lubbers, M and Scheepers, P. (2000), "Exposure to newspapers and attitudes toward ethnic minorities: A longitudinal analysis", Howard Journal of Communications, Vol. 11 No.2, pp. 127-43.

Wiek, A. Ries, R. Thabrew, L. Brundiers, K. and Wickramasinghe, A. (2010), "Challenges of sustainable recovery processes in tsunami affected communities", Disaster prevention and management, Vol. 19 No.4, pp. 423 - 37.

Voorhees, C.W. Vick, J.and Perkins, D.D. (2007), "'came hell and high water': The intersection of Hurricane Katrina, the news media, race an poverty", Journal of Community and applied social psychology, Vol. 17 No.6, pp. 415-29.

\footnotetext{
${ }^{\mathrm{i}}$ Including not only media studies of the Indian Ocean tsunami the number of publications is very large and range from investigations of social impacts (e.g. Rodriguez, et al., 2006) to studies of long term recovery (e.g. Wiek, et al., 2010).

${ }^{\text {ii }}$ Swedish newspapers published almost 50 times as many articles about hurricane Katrina compared to Stan, which is reflected in two of the largest newspapers; Dagens Nyheter published 4 articles about Stan and 141 about Katrina, and Svenska Dagbladet published 7 about Stan and 356 about Katrina (Sällström, 2006).
} 
How to cite: Anna Olofsson, (2011) "The Indian Ocean tsunami in Swedish newspapers: nationalism after catastrophe", Disaster Prevention and Management, Vol. 20 Iss: 5, pp.557 569

iii A discourse can be described as a set of coherent expressions, statements and concepts. It is based on the notion that people's entire relationship to reality is expressed through discourses, and the discourse governs the understanding of reality. 